\title{
Bank Charges for Insufficient Funds Checks*
}

Demand deposit accountholders may write checks for amounts that exceed the funds on deposit in their accounts. Such checks are known as NSF (not sufficient funds) checks. Banks charge special fees for the processing of NSF checks. In California, these fees range typically froin four to nine dollars, ${ }^{1}$ although the average cost for processing an NSF check is about seventy-five cents. ${ }^{2}$ The disparity between the cost of processing NSF checks and the charges assessed for them has led to the filing of numerous lawsuits in California that challenge these charges. ${ }^{3}$

* The idea for this Comment arose from the author's employment as a law clerk by $\mathrm{e}$. robert (bob) wallach, David B. Baum, and Manuel Glenn Abascal of San Francisco, attorneys for plaintiffs in several of the actions listed at note 3 infra. The opinions expressed herein are solely those of the author.

1. For exainple, Bank of America charges $\$ 4.00$, Facts About Bank of America's Checking and Savings Programs 14 (April 1980), while Security National Bank charges $\$ 9.00$, Security National Bank, Form OPP-18 (July I, 1980).

2. Bank Administration Institute, The Impact of Exception ltems on the Check Collection System 25 (1974). This industrywide study of checks that cannot complete the normal collection process set an average cost per bank for returned items (mostly NSF checks, but including stopped payments, closed accounts, and other returns not caused by technical processing problems) at \$0.29. An average of 2.6 mstitutions handled each item. Thus, the average total cost per returned item was $\$ 0.75$. Id.

By another measure, Bank of America's "Decimus" data processing service, available to other banks, charges $\$ 0.15$ per NSF itein for all necessary bookeeping and preparation of notices; the other major cost component, not performed by Decimus, is mailing the notice to the maker. Decimus Corporation, Branch Procedures Manual, Figure 3-3 (July 1975); Decimus Corporation, Demand Deposit Accounting System 4-100-4-103 (April 1976).

3. Among the pending actions are the following: Stack v. Bank of Marin, No. 98329 (Marin Super. Ct., filed May 9, 1980); Perdue v. Crocker Nat'1 Bank, appeal docketed, 1 Civil 46808 (1st Dist. March 23, 1979); Pauling v. Security Pac. Nat'l Bank, No. 742-672 (S.F. Super. Ct., filed July 3, 1978); Waller v. Bank of America, No. 740-353 (S.F. Super. Ct., filed July 3, 1978); Sweet v. Sumitomo Bank, No. 727-750 (S.F. Super. Ct., filed Sept. 6, 1977); Huffman v. Union Bank, No. 724-576 (S.F. Super. Ct., filed June 20, 1977); Hanks v. United Cal. Bank, No. $722-193$ (S.F. Super. Ct., filed April 27, 1977); Clinton v. Crocker Nat'l Bank, No. $722-192$ (S.F. Super. Ct., filed April 27, 1977); Peterson v. Wells Fargo Bank, No. 722-191 (S.F. Super. Ct., filed April 27, 1977); Childhouse v. Bank of America, No. 722-190 (S.F. Super. Ct., filed April 27, 1977); O'Neal v. Chartered Bank of London, No. $721-675$ (S.F. Super. Ct., filed April 15, 1977); Cambell v. Lloyds Bank, No. 721-624 (S.F. Super. Ct., filed April 15, 1977); Murphy v. Alameda First Nat'l Bank, No. 494172-1 (Alameda Super. Ct., filed April 14, 1977); Jones v. Security Nat'l Bank, No. 494171-2 (Alameda Super. Ct., filed April 14, 1977); Katechis v. Central Bank, No. $493170-4$ (Alameda Super. Ct., filed Mar. 18, 1977); Glover v. United Cal. Bank, No. CA 000450 (L.A. Super. Ct., filed Mar. 17, 1977); Maietta v. Bank of Cal., No. 720-310 (S.F. Super Ct., filed Mar. 17, 1977); Abascal v. Crocker Nat'l Bank, No. $720-309$ (S.F. Super. Ct., filed Mar. 17, 1977); Wilson v. Bank of America, No. 720-308 (S.F. Super. Ct., filed Mar. 17, 1977); Rogers v. Wells Fargo Bank, No. 720-307 (S.F. Super. Ct., filed Mar. 17, 1977); Sanchez v. Security Pac. Nat'l Bank, No. 720-306 (S.F. Super. Ct., filed Mar. 17, 1977). 
This Comment exammes the issues necessary to determine the legality of the banks' current levels of NSF charges. First, the Comment analyzes the validity of the NSF charge under contract law. It concludes that agreements to NSF charges at the current levels should be unenforceable because such high charges are penalties rather than provisions for liquidated dainages or alternative methods of performance. The Comment then considers whether the need to deter accountholders from writing checks against insufficient funds justifies excessive NSF charges, and whether there are other means to achieve the goal of NSF check reduction.

\section{I}

NSF Charges-The FACTUAL SeTting

A bank usually offers a choice of different checking plans to a custoiner wishing to open an account. Plans differ in cost depending upon the price per check, which may vary with the number of checks written and the average or minimum balance kept on account. The recently enacted California Financial Code section 865 prohibits banks from accepting a first deposit prior to furnishing the depositor with a written statement of charges that the bank may inake for regular services. ${ }^{4}$

At the time when the bank and the customer agree to open the checking account, the bank presents the customer with a document labeled "Signature Card." The card usually contains blank spaces that the customer fills in with basic identification information, the type of account, authorization for the bank to mail statements, and the signature of the accountholder.

Typically, the signature card states that the depositor agrees that the bank's rules, regulations, by-laws, and practices, including all future amendments that the bank may adopt, will govern the account. ${ }^{5}$ The bank's rules and practices include its provisions for NSF charges. Banks consider the signature card and referenced documents to constitute a contract controlling the account. ${ }^{6}$ But the banks generally do not provide the customer with a copy of the card or any of the materials to which it refers. ${ }^{7}$

4. CAL. Fin. Code $\$ 865.4$ (West Supp. 1980), added by 1976 Cal. Stats. 5672, ch. 1279, \&1.

5. See, e.g., Wells Fargo Banks, General Signature Card, Form DAI 10-72-02105; Crocker National Bank, Signature Card-General, Form 05-300 (Oct. 1975); Bank of California, General Signature Card-Individual, Form NA-9679 (Jan. 1975).

6. See, eg., Memorandum of Poimts and Authorities in Support of Defendant's Motion for Judgment on the Pleadings at 9-13, Abascal v. Crocker Nat'l Bank, No. $720-309$ (S.F. Super. Ct., filed Oct. 10, 1978).

7. The Bank of America now gives the cutomer a copy of a "Bank-Depositor Agreeinent," Forn TEL-100 (Dec. 1975). 
II

\section{LEGALITY OF THE NSF CHARGE}

The relationship of a checking account customer to the drawee bank is that of creditor and debtor. ${ }^{8}$ The bank receives the interest-free use of the customer's deposits in exchange for repayment upon deinand and the convenience of using the bank's checking account services. One of the terms of the contract between the bank and a customer is that the customer will pay the bank's NSF charge for each check presented against the custoiner's account that exceeds the funds on deposit. ${ }^{9}$

Simply because the parties have agreed that the bank will charge the customer a given alnount for each NSF check that is presented to the bank does not insure that that contractual term is enforceable. Terms that are agreed upon may be void if, for example, they are unconscionable, illegal, or contrary to public pohicy. ${ }^{10}$ A contractual term that is a penalty intended to coerce proper performance by one of the parties will not be enforced. ${ }^{11}$ The primary issue under contract theory is whether the agreement to pay NSF charges is properly characterized as an option for alternative performance of the contract at a given price, an agreeinent to pay liquidated damages, or an unlawful penalty. ${ }^{12}$

A court inay ultimately characterize the term differently from the parties; the label in the contract is considered but does not control. ${ }^{13}$ The transactions that occur when the account is opened and the subsequent behavior of the parties leave the exact nature of the term estab-

8. E.g., Bank of Marin v. England, 385 U.S. 99, 101 (1966); Weaver v. Bank of America, 59 Cal. 2d 428, 431, 380 P.2d 644, 647, 30 Cal. Rptr. 4, 7 (1936).

9. It is not clear whether the basis of the customer's agreement to pay the NSF charge is an express written agreement or one that is implied in fact. In some of the current litigation, plaintiff' position is that there is no express contract created by the customer signing the signature card, because the card only represents an agreement that the bank will not pay out the customer's money without proper identification. They argue instead that the bank-depositor relatiouship is implied in fact. See, e.g., Memorandum of Points and Authorities in Support of Plaintiff's Petition for Writ of Mandate at 35-52, Rogers v. Wells Fargo Bank, No. 720-307 (S.F. Super. Ct., filed June 26,1980 ). The attempted distinction should have no bearing on the outcome of the litigation, lowever. The depositor's acceptance of the bank's price schedule upon opening the account, including the announced NSF cliarges, would fairly imply an agreement to pay the stated charges.

10. See, e.g., Tunkle v. Regents of the Univ. of Cal., 60 Cal. 2d 92, 98-101, 383 P.2d 441, 444-47, 32 Cal. Rptr. 33, 36-39 (1963) (contrary to public policy); CAL. Civ. CODE $§ 1670.5$ (West Supp. 1980) (unconscionable); id. $\S 1667$ (West 1973) (unlawful).

11. Muldoon v. Lynch, 66 Cal. 536, 539, 6 P. 417, 418 (1885); see Garrett v. Coast \& S. Fed. Sav. \& Loan Ass'n, 9 Cal. 3d 731, 740, 511 P.2d 1197, 1203, 108 Cal. Rptr. 845, 851 (1973).

12. Cf. Garrett v. Coast \& S. Fed. Sav. \& Loan Ass'n, 9 Cal. 3d 731, 735-42, 511 P.2d 1197, 1199-1204, 108 Cal. Rptr. 845, 847-52 (1973) (discussion of late charges on loans secured by real property).

13. 5 A. Corain, Contracts $\S 1058$, at $337-38$ (2d ed. 1964); 5 S. Williston, Contracts \$ 781, at 705-06 (3d cd. W. Jaeger 1961). 
hishing NSF charges uncertain. Some bank literature distributed to depositors advises that a depositor should keep a balance sufficient to cover all checks that are drawn on the account, and warns that the bank may close an account if presented with too many NSF checks. ${ }^{14}$ While this might suggest that writing an NSF check is a breach of the agreement it is not clear whether these statements oblige the depositor not to write NSF checks, or merely advise careful recordkeeping as a good business practice. Often other bank literature, including price disclosure statements, explains the charge as compensation for the extra handling that NSF checks require. ${ }^{15}$ These statements suggest that the charge is a stipulated or liquidated damage agreement. However, analysis of the NSF charge establishes that it is neither a valid service charge nor a liquidated damage term, but rather is an unlawful penalty.

\section{A. NSF Charges As Alternative Performance}

The test for deciding whether a term provides for a performance alternative or a penalty should be whether the promisor might reasonably have conceived the alternative promise as an equivalent or potentially more desirable alternative. ${ }^{16}$ If not, then the term states a penalty. Thus, an unreasonably high price for an alternative of little utility suggests that the alternative should be interpreted as a penalty rather than a performance option. ${ }^{17}$

Analysis of whether the NSF charge term provides a viable alternative involves considering both the price and the nature of the perfornance. A price for alternative performance that is many times its cost does not seem reasonable. And it is unlikely that a bank depositor would reasonably beheve that a checking account agreenent includes the privilege of writing NSF checks at will. Writing an NSF check is at best a civil wrong, at worst, a crime. The depositor may not reasonably expect that the bank has entered into an agreement that allows for the performance of an unlawful act. In addition, courts generally prefer to construe ambiguities in contracts so that the performance of the contract is lawful rather than illegal. ${ }^{18}$

14. E.g., Bank of America, How to Balance Your Checkbook 1 (1979): "You are responsible, of course, for not writing checks for more money than you have in your account."

15. E.g., Lloyds Bank, Facts About Our Checking and Savings Accounts 3 (Consumer Disclosure Statenent AC-149 (Aug. 1976)); United California Bank, Let's Talk About UCB Deposit Accounts 5 (Dec. 1980).

16. C. McCormick, Handbook on the LaW of Damages $\S 154$, at 618 (1935); 5 S. WiLLISTON, supra note 13, § 781, at 705; Sweet, Liguidated Damages in California, 60 CAL1F. L. REv. 84, 141 (1972).

17. See 5 A. Corain, supra note $13, \S 1063$, at 362.

18. E.g., Apra v. Aureguy, 55 Cal. 2d 827, 831, 361 P.2d 897, 899, 13 Cal. Rptr. 177, 179 (1961); see CAL. Civ. Code $\$ 1643$ (West 1973); id. § 3541 (West 1970). 
The making of an NSF check, even unintentionally, breaches a contract to pay for goods or services received or promised. ${ }^{19}$ A check is an express written contract, promising payınent on deınand. ${ }^{20} \mathrm{~A}$ contract is illegal if its performance requires the breach of a contract with a third person. ${ }^{21}$ The checking account agreement does not require that the depositor draw any checks against insufficient funds, of course. But if the accountholder has an option to write such a check and pay charges, then exercise of the option requires an unlawful act, i.e., breaking a contract to pay money to the merchant or other person who was given the check. A term that involves an unlawful act can hardly be legally recognized as a "reasonable" alternative performance. ${ }^{22}$

That the writing of an NSF check is unlawful is further demonstrated by various statutory provisions that either provide a penalty for writing NSF checks, or whose underlying policy is frustrated by such checks. An act for which a statute provides a penalty is unlawful regardless of whether the statute expressly prohibits the act. ${ }^{23}$ For example, the provisions of Califorma Government Code section 6157 that allow state agencies to receive personal checks as payinent also provide that if a check is returned unpaid for any reason, the drawer, regardless of knowledge and intent, inay be charged up to ten dollars and denied the privilege of paying by personal check in the future. ${ }^{24}$ The charge of up to ten dollars may be intended only to collect actual dainages, and therefore might not be a penalty, but the demal of the privilege of payment by personal check has no coinpensatory goal and therefore inust be a penalty. Issumg an NSF check to the state is thus unlawful under the Government Code. It should not be any more lawful to issue an NSF check simply because the recipient is a private party rather than the government. ${ }^{25}$

19. CAL. COM. CODE $\$ 2511$ (West 1964) (dishonor of a check received as payment for goods constitutes grounds for rescinding the contract of sale).

20. See Roff v. Crenshaw, 69 Cal. App. 2d 536, 539-41, 159 P.2d 661, 662-63 (2d Dist. 1945).

21. Restatement of Contracts $§ 576$ (1932); see Moody v. Newmark \& Edwards, 121 Cal. 446, 448, 53 P. 944, 945 (1898) (sales contract); Rosenberg v. Raskin, 80 Cal. App. 2d 335, 338-39, 181 P.2d 897, 899 (2d Dist. 1947) (employment contract).

22. The making of an NSF check possibly could be analyzed as a condition precedent rather than as an alternative performance. Under this analysis, the depositor creates the condition by causing a check to be presented against insufficient funds, whereupon the bank performs by processing the check (even though the processing may result in the check being dishonored). However, CAL. Clv. CODE $\S 1441$ (West 1954) provides that an unlawful condition precedent is void. Thus, writing an NSF check can be neither an alternative performance nor a condition precedent. If the bank-depositor contract is to be construed so as to be lawful, then the NSF check must be treated as a breach.

23. E.g., Severence v. Knight-Counihan Co., 29 Cal. 2d 561, 568, 177 P.2d 4, 8 (1947).

24. CAL. Gov'T CODE $\S 6157$ (West Supp. 1980).

25. Because a check is an unconditional promise to the payee that the stated amount will be received upon presentment at the payor bank, the issuance of an NSF check may in some circumstances be more clearly illegal. Compare CAL. PENAL CODE $\S 476$ (a) (West 1970) (felony if prom- 
The policy underlying the laws prohibiting NSF check writing is the protection not merely of the bank but of the general public as receivers and indorsers of negotiable paper. ${ }^{26}$ Contracts may be void as against underlying statutory policy even if they do not violate a specific statute. ${ }^{27}$ In sum, the law does not allow an interpretation of the agreeinent on the NSF charge as a inethod of alternative performance, because that performance is unlawful and contrary to public policy.

\section{B. NSF Charges As Liquidated Damages}

Fixed dainages set $\mathrm{m}$ anticipation of a breach of contract in a consumer setting are presuined to be unlawful. ${ }^{28}$ The damage provision nay be justified only if the actual dainages in the event of the breach are difficult or impossible to determine at the time of contract formation and the fixed damage ainount represents an agreement of both parties as to a reasonable estimate of the actual dainages. ${ }^{29}$ The policy behind this rule is that dainages for breach of contract are compensatory rather than punitive. ${ }^{30}$

The various studies that have been inade to determine the cost of NSF check processing have fixed the cost at about seventy-five cents. ${ }^{31}$ Some banks may have done their own cost studies, and thus would be able to determine the cost precisely. Others could rely on industrywide figures in making a reasonable estimate of actual dainages. A bank seeking to enforce its stated charge as a valid fixed damage provision would have the burden of proving first, that at the time of contract

ise made with fraudulent intent) with Massei v. Lettunich, 248 Cal. App. 2d 68, 73, 56 Cal. Rptr. 232, 235 (Ist Dist. 1967) (actionable tort of intentional misrepresentation if promise made with knowledge of present insufficiency but no fraudulent intent) and Gagne v. Bertran, 43 Cal. 2d 481, 487-88, 275 P.2d 15, 20 (1954) (negligent misrepresentation is actionable tort if detrimentally relied upon).

26. Cf. People v. Superior Court (Abrahms), 55 Cal. App. 3d 759, 771, 127 Cal. Rptr. 672, 680 (2d Dist. 1970) (CAL. Penal CODE $\$ 476$ (a) violation requires intent to defraud person to whom check was dehivered, not intent to defraud the bank). See generally Comment, Insufficient Funds Checks in the Criminal Area: Elements, Issues, and Proposals, 38 Mo. L. REV. 432, 433-34 (1973).

27. Cal. Civ. Code $\S 1667(2)$ (West 1973); see, e.g., Altschul v. Sayble, 83 Cal. App. 3d 153, 162, 147 Cal. Rptr. 716, 720 (2d Dist. 1978).

28. Cal. Civ. Code $\S 1671$ (d) (West Supp. 1980). Until 1977 a liquidated damage clause was presuined invalid in any context. CAL. CIV. CODE $\$ 1670$ (superseded) (West 1973). However, a presuinption of invalidity is not sound policy in a commercial setting, where such clauses may be economically beneficial. See Sweet, supra note 16, at 86-87.

29. E.g., Garrett v. Coast \& S. Fed. Sav. \& Loan Ass'n, 9 Cal. 3d 731, 738-39, 511 P.2d 1197, 1203, 108 Cal. Rptr. 845, 850 (1973); McCarthy v. Talley, 46 Cal. 2d 577, 586, 297 P.2d 981, 987 (1956); United Sav. \& Loan Ass'n v. Reeder Dev. Corp., 57 Cal. App. 3d 282, 298-99, 129 Cal. Rptr. 113, 123 (2d Dist. 1976).

30. See MacFadden v. Walker, 5 Cal. 3d 809, 813-14, 488 P.2d 1353, 1354, 97 Cal. Rptr. 537, 539 (1971); Freedman v. The Rector, 37 Cal. 2d 16, 21-22, 230 P.2d 629, 632 (1951); CAL. Civ. CodE $\$ \S 3300,3369$ (West 1970).

31. See note 2 supra. 
formation it was difficult to determine the actual damages, and second, that both parties agreed on the charge as a reasonable estimate of the bank's actual damages. ${ }^{32}$ The former would be difficult to prove im light of the studies that have fixed the cost im a range far below the amount currently charged, and the great similarity in processing techniques and equipment used by banks. The latter factor assumes that the term was bargaimed over by the parties. In light of the bank's exclusive knowledge of the precise amount of damages involved, a full disclosure of that knowledge would be necessary for the term to be set bilaterally. Thus, an agreement for NSF charges ranging from four to nine dollars, for damages that might reasonably have been estimated at seventy-five cents, is not a valid liquidated damage provision but rather an unlawful penalty under California Civil Code section $1671(\mathrm{~d}) .^{33}$

\section{III}

\section{The Need for Alternative Methods of Deterrence}

One problem with the invalidation of agreements to pay NSF charges at current levels is that if the depositor were only required to pay actual damages of less than one dollar, there would be less of a disincentive to write NSF checks than exists currently. Although there are sound policy reasons for discouraging the writing of NSF checks, the law does not allow parties to a contract to set damages for violations of the contract in excess of a compensatory amount. ${ }^{34}$ One private party may not agree that another private party may penalize him for his wrongful acts.

An exception to the rule prohibitimg penalty provisions and pumitive damages for breach of contract should be allowed only if a compelling justification exists. However, the possible deterrent effect of the current system of NSF check charges does not present such a justification for abandoning the present per se rule agamst penalty provisions in contracts. Opening the possibility of a case-by-case approach to penalties, whenever the party exacting the punitive sum could claim to be protectimg the public interest, would likely lead to an abundance of litigation. Moreover, in the case of NSF charges there are competing

32. See Garrett v. Coast \& S. Fed. Sav. \& Loan Ass'n, 9 Cal. 3d 731, 738, 511 P.2d 1197, 1203, 108 Cal. Rptr. 845, 850 (1973); United Sav. \& Loan Ass'n v. Reeder Dev. Corp., 57 Cal. App. 3d 282, 298-99, 129 Cal. Rptr. 113, 123 (2d Dist. 1976).

33. CAL. Civ. CoDE $\S 1671$ (d) (West Supp. 1980).

There is soine acknowledgement even within the banking industry that NSF charges are punitive. "Late payınent charges and overdraft fees are not strictly charges for service, but "character building' punishinents - so that is probably why we feel much more righteous about pushing thein up high enough to more than cover our costs." Goldberg, Researching Banking Fee Services, 1512 Bankers Magazine 83, 84 (1968).

34. See CAL. CIV. CodE $\$ \S 3275,3300,3369$ (West 1970). 
policies that suggest that no compelling justification for such charges exists.

If the wrongful acts of a private party will enrich another private party, there exists an mducement for the latter to encourage that wrong, and thereby reduce the deterrent effect. ${ }^{35}$ Such a possibility exists in the case of NSF check charges, smce banks can exercise some control over the number of NSF checks, as detailed below.

\section{A. Potential for Abuse of the NSF Charge}

Because the bank receives a large profit on each NSF check for which the depositor pays the charge, the bank's imterest in increasing its profits may conflict with the public imterest in reducing the frequency with which NSF checks occur. This potential conflict occurs because the bank controls the check posting sequence and so has the ability to manipulate the occurrence of NSF checks.

The common law rule was that banks had to post debts and credits in the order received. ${ }^{36}$ The large volume of transactions handled by banks, and the effects of high-speed processing by clearinghouses, have made this a practical impossibility. ${ }^{37}$ Hence, Cahfornia Commercial Code section 4303(2), the California counterpart to Uniform Commercial Code section 4-303(2), permits a bank to post debits and credits received on the same day " $m$ any order convenient to the bank."38 The official commentary to the Code justifies this provision by stating that the drawer "should have funds available to meet all of the checks drawn and has no basis for urging one should be paid before another." 39 This section may provide authority for banks to arbitrarily determine the posting sequence. ${ }^{40}$

Thus, there appears to be opportunity for the bank to use its control over the postimg sequence to its advantage. For example, if an account has a balance of thirty dollars, and checks agamst that account are presented on the same day im the amounts of twenty-five, fifteen, and ten dollars, the bank has the option of paying the twenty-five dollar check and not the other two, or vice versa. It is im the bank's inter-

35. See Clarkson, Miller \& Muris, Liquidated Damages v. Penalties: Sense or Nonsense?, 78 WIS. L. REV. 351, 375, 388-90 (1978).

36. Note, The Proposed Unjform Commercial Code: Bank Deposits and Collections, 50 Colum. L. REv. 802, 820-21 (1950); see Louisville \& N. R.R. v. Federal Reserve Bank, 157 Tenn. 497, 10 S.W.2d 683 (1928); Castaline v. National City Bank, 244 Mass. 416, 138 N.E. 398 (1923).

37. See Leary, Check Handling Under Article Four of the Uniform Commercial Code, 49 MARQ. L. REv. 331, 334-37 (1965); Note, supra note 36, at 819-22.

38. Cal. Com. Code $\$ 4303(2)$ (West 1964); see New Jersey Bank v. Palladino, 146 N.J. Super. 6, 14, 368 A.2d 943, 947 (1976) (interpreting the state's U.C.C. counterpart).

39. CAL. CoM. Code $\S 4303$, Official Comment No. 6 (West 1964).

40. Wasson, Bank to Customer Relations Under the Uniform Commercial Code: Article IV, 16 ARK. L. REV. 66, 68 (1961-62). 
est to choose the first option and collect twice as much in NSF charges, despite the likelihood that two NSF checks would cause greater harm than one because they would affect more transactions. The bank could do this even if it actually received the two smaller checks earlier in the banking day.

Similarly, if the depositor lias deposited funds sufficient to cover the checks on the same day that they are presented for collection, the bank miglit post the deposit credit after the debit items, and refuse to pay the checks, even if the credit item actually arrived at the bank earlier than the debits. ${ }^{41}$

Althouglı a bank is not a fiduciary in its role as the depositor's debtor, ${ }^{42}$ when a bank has received an item for collection it acts as the depositor's agent until it receives payment for the item. ${ }^{43}$ The bank is obligated to use ordmary care in the collection process, ${ }^{44}$ and, as an agent for the collection of a negotiable instrument, the bank is also obliged to act promptly. ${ }^{45}$ This obligation should require that the bank post credits to the account as soon as possible. But, as detailed above, the bank controls the sequence in which it posts debits and credits and so lias the power to create unnecessary NSF charges by posting debit items ahead of credits received on the same day even if those credits would have been sufficient to cover the debit items. The bank's interest in increasing its revenues, by assessing avoidable NSF charges, may thus conflict witli its duty as an agent to collect and post credits promptly. Limitation of the NSF charge to a compensatory amount would eliminate this possible conflict of interest, smce the bank would not stand to profit by wliat is arguably a dereliction of its duty.

Banks may not now prograin their posting computers to create inore NSF checks than necessary. But allowing the banks to overcharge for NSF cliecks creates an incentive for them to abuse tlieir control over posting procedures to the detriment of their depositors. Moreover, the present high level of charges does not encourage a force-

41. In fact, some banks have a separate charge for a deposit posted later in the day than a check that required those funds to be paid. These banks will pay the checks, but still charge the depositor a "late deposit" fee, usually an amount less than the NSF charge. United California Bank charges $\$ 5.00$ for a late deposit, and $\$ 6.00$ for a returned ("bounced") NSF check or an overdraft (a check drawn against insufficient funds that the bank pays anyway). United California Bank, UCB Schedule of Account Fees and Rates (May, 1980). Security Pacific National Bank charges $\$ 4.00$ for a "temporary overdraft" (late deposit), and $\$ 5.00$ for a returned check or an overdraft. Security Pacific National Bank, Service Charges and Interest Rates for Checking and Savings Prograins (Dec. 1, 1980).

42. E.g., Smith's Cash Store v. First Nat'l Bank, 149 Cal. 32, 34-35, 84 P. 663, 664 (1906).

43. E.g., Cooper v. Union Bank, 9 Cal. 3d 371, 378, 507 P.2d 609, 614, 107 Cal. Rptr. 1, 6-7

(1973); CaL. CoM. Code $§ 4201$ (1) (West 1964).

44. Cal. Com. Code $\S 4202$ (West 1964).

45. CaL. CIV. Code $\S 2021$ (West 1954). 
ful policy against NSF checks on the part of the banks. If the charges are lowered to somewhere near cost, they becoine a minor inconvenience rather than a source of profit. Banks may then be expected to emphasize inore strongly to depositors their oppostion to the practice of writing NSF checks.

\section{B. Effective Deterrence Without NSF Charges}

It may not be necessary for other charges or penalties to replace the current punitive NSF charges. Intentional writing of checks without sufficient funds to pay them is illegal. NSF checks issued to nierchants may result in the affected merchants refusing to accept further checks from the offending custoiners, or themselves assessimg a handling cliarge. Unintentional NSF checks inay cause friction between, for example, landlord and tenant. Generally, writing NSF checks gains little and causes problems for the writer, apart from any NSF charges.

Although conflict with the payee would continue as a disincentive to NSF check writing if the present systein of charges were invalidated, reduction of the charge would probably lead to increased numbers of NSF checks. Thus, it would be sound policy to deter NSF checks by other means.

\section{Closing Accounts}

Habitual writers of NSF checks might stop the practice if the banks were to make it clear that the writing of an NSF check is a material breach of the checking agreenent. One way to do this would be for banks to terminate accounts on which substantial numbers of NSF checks are presented. Such a policy might require banks to revise their literature and communications to their depositors so that the banks give the depositors more notice of the seriousness with which they regard NSF checks. Banks would close accounts not only on the basis of the number of NSF checks presented, but also on the basis of the custoiner's pattern of abuse. Evidence of unintentional NSF checking should delay closing the account; the bank should first attempt to explain to the customer how NSF checks occur, in the hope that education will decrease the frequency of the customer's NSF checks. Simce cliecking accounts are nearly a necessity of life in today's economic systein, ${ }^{46}$ a policy of closing accounts would decrease the number of NSF checks written by habitual check bouncers. Either they voluntarily would write fewer NSF checks, or they would have their accounts

46. Burrows v. Superior Court, 13 Cal. 3d 238, 247, 529 P.2d 590, 596, 118 Cal. Rptr. 166, 172 (1974). 
closed and thus be forced to write fewer such checks. Habitual check bouncers nay now find the inconvenience of balancing their checkbook inore onerous than paying NSF charges. However, they might not find accurate recordkeeping nore inconvenient than coinplete loss of the checking privilege.

\section{Statutory Penalties}

A punitive fee probably does discourage the occasional, as opposed to habitual, check bouncer. Such a person would not need to worry about having a checking account closed, but might respond to the economic incentive of a punitive charge for each NSF check. If the courts do invalidate the current system of bank charges, the legislature should enact a statute providing for a civil penalty of about five dollars for writing an NSF check. The statute would einpower the bank to collect the charge for the state and deduct from it the bank's costs of both processing the check and collecting the penalty. The bank would remit the balance to the state, in a manner similar to that used by merchants in remitting sales taxes.

\section{Delayed Return of Small NSF Checks}

Another way for banks to decrease the number of NSF checks would be to allow custoniers inore time to deposit funds to cover the checks. There is evidence indicating that many NSF checks occur because the depositor intended to cover the clieck, but was unable to make a deposit in time or miscalculated the speed with which checks are collected through the clearinghouse system. Over half of all NSF checks that are resubnnitted by the collecting bank are paid upon the second presentment. ${ }^{47}$ Banks could therefore reduce the number of NSF cliecks substantially if such checks were held for a longer period before being returned. This is not currently possible under the Commercial Code, simce a payor bank must return a rejected item by midnight on the day following its receipt. ${ }^{48}$ One industry study suggested extending the deadline for return of NSF items under twenty-five dollars to seventy-two hours. ${ }^{49}$ Forty-six percent of all NSF cliecks are written for under twenty-five dollars..$^{50}$ Of these, about seventy-five percent would be paid if held for the proposed seventy-two lour pe-

47. See Bank Administration Institute, The Impact of Exception Items on the Check Collection System 29 (1974) (75\% of resubmitted items are paid on the second presentment); Leary, supra note 37, at 333 n.7 (citing Federal Reserve Bank studies showing that about half of the items mitially dishonored are paid upon re-presentment).

48. CAL. Com. Code $\S 4302$ (West 1964).

49. See Bank Administration Institute, Recommendations For Exception Item Reduction 66-69 (1975).

50. Id. at 66 . 
riod. ${ }^{51}$ Total NSF checks would thus be reduced by nearly thirty-five percent. ${ }^{52}$ Hence, amending the Commercial Code to extend the deadline for returning small rejected items would be an effective means of reducing the numbers of NSF checks.

\section{CONCLUSION}

The bank charge for NSF checks is a penalty provision and not a legitimate provision for alternative performance or for liquidated damages. Elimination of the present system of penalties would serve the public interest by creating an incentive for banks to take positive and legal steps to reduce NSF check occurrence. Such steps might include education of depositors, closing accounts that imdicate an abusive pattern of msufficient funds checking, and alterations in the posting process to eliminate unnecessary creation of NSF checks. It would be desirable to accompany these steps with a statutory enactment of civil penalties for NSF checks, and an extension of the rejection deadlime for NSF checks written for small amounts. These steps should effectively reduce the occurrence of such clecks, without contravening contract law.

Howard M. Klepper*

51. Id. at $66-67$.

52. The $\$ 25.00$ figure was suggested in order to mimimize the risk that check kiters might take advantage of the extension. Id at 68 . Actual losses due to fraud currently amount to $\$ 0.03$ per NSF check. Bank Administration Institute, The Impact of Exception Items on the Check Collectiou System 26 (1974).

* B.A. 1970, University of Wisconsim; third-year student, Boalt Hall School of Law. 